\title{
Kepemimpinan Transformasional Di Era Post Modern
}

\author{
Wasis Suseno \\ Sekolah Tinggi Teologi Moriah Gading Serpong \\ wasisssn@gmail.com
}

\begin{abstract}
The modern Post era we are currently facing has the character of: attacking the special, universal, total, and absolute status of truth as understood in modernism. Single and universal truths are not recognized. There are only true truths for every society or community. Then truth is understood as fragmented into equal truths without a single normative accout beyond it. There is no tradition or ideology that stands on other traditions or other ideologies. What one believes to be true is no longer a single truth but part of truth pluralism. Therefor a leader understands the leadership of transformation in the post moderent era, apostle Paul explains, there are three levels of Transformational in the life of Believers, namely: 1) Position Transformation; 2) Behavior Transformation; 3) Community Transformation. If we can describe, the leadership of transformation in post-modern era, must have three real roles in leadership, 1. Spiritual Formation, 2. Theological Proficiency, 3. Practical \& Ministry Proficieny. These three skills will be discussed in this paper.
\end{abstract}

Keywords: Leadership, Post-modern, Transformation

Abstrak: Era Pos modern yang kita hadapi saat ini bersifat: menyerang status kebenaran yang khusus, universal, total, dan absolut sebagaimana dipahami dalam modernisme. Kebenaran tunggal dan universal tidak diakui. Hanya ada kebenaran sejati untuk setiap masyarakat atau komunitas. Kemudian kebenaran dipahami sebagai terfragmentasi menjadi kebenaran yang setara tanpa satu pernyataan normatif di luarnya. Tidak ada tradisi atau ideologi yang berdiri di atas tradisi atau ideologi lain. Apa yang diyakini sebagai kebenaran bukan lagi kebenaran tunggal melainkan bagian dari pluralisme kebenaran. Untuk itu seorang pemimpin memahami transformasi kepemimpinan di era post moderent, Rasul Paulus menjelaskan, ada tiga tingkatan Transformasi dalam kehidupan Orang Beriman, yaitu: 1) Transformasi Jabatan; 2) Transformasi Perilaku; 3) Transformasi Komunitas. Jika bisa kita gambarkan, kepemimpinan transformasi di era postmodern, harus memiliki tiga peran nyata dalam kepemimpinan, 1. Formasi Spiritual, 2. Kecakapan Teologis, 3. Practical \& Ministry Proficieny. Ketiga keterampilan tersebut akan dibahas dalam makalah ini.

Kata Kunci: Kepemimpinan, Post-modern, Transformasi

\section{Pendahuluan}

"Yang kurang di negeri kita bukanlah pemimpin, melainkan orang yang berkualitas memimpin dan yang menjalankan peran kepemimpinan."1 Pernyataaan di atas sangat

${ }^{1}$ Eka Dharma Putra, "Kepemimpinan dalam Pendidikan Agama Kristen”, dalam kumpulan tulisan Bergumul Dalam Pengharapan (Jakarta: BPK Gunung Mulia, 2004), 759. 
jelas, bahwa salah satu faktor penyebab terjadinya krisis kepemimpinan di gereja-gereja atau lembaga-lembaga pelayanan Kristen di Indonesia saat ini, karena "Pemimpin yang menjalankan peran kepemimpinan." Hal ini menyangkut kualifikasi seorang pemimpin dari segi intelektual, edukasi, karakter, moral, serta segi spiritual. Faktor penyebabnya, pemimpin tidak dipersiapkan sejak dini atau sejak ia masih kecil, melainkan lebih sering karena penunjukkan langsung oleh pemimpin sebelumnya, misalnya karena kedekatan emosional atau paling sering karena masih ada hubungan keluarga.

Bagaimana sesungguhnya kualifikasi seorang pemimpin yang berkualitas? Patut menjadi bahan evaluasi dan introspeksi bagi kita, agar dapat menemukan kualifikasi seorang pemimpin yang sesungguhnya, apa lagi di dalam kepemimpinan Kristen. Ketika memilih seorang pemimpin, siapa yang dipilih? Apakah orang yang baik hati, orang yang paling tegas, orang yang paling jujur? Apa yang menjadi kualifikasi seorang pemimpin?

Tentu akan berdampak buruk ketika memilih seorang pemimpin dengan sembarangan, sebab secara mendasar, s=pemimpin melambangkan citra diri dari sebuah kelompok. Tetapi seringkali urusan tentang pemimpin justru menjadi sumber kontroversi. Pemimpin yang pilih kasih akan menimbulkan perpecahan dalam kelompok. Pemimpin yang mementingkan kekuasaan akan melahirkan penjilat-penjilat. Pemimpin yang korup akan menjadikan kelompok itu juga korup. Karena itu, tiap kelompok membutuhkan pemimpin yang berjiwa kepemimpinan.

Pemimpin dan kepemimpinan belum tentu identik. Seorang pemimpin belum tentu berjiwa kepemimpinan, sebab bisa jadi ia berkedudukan pemimpin karena ia memaksakan diri. Demikian juga tidak semua orang berjiwa kepemimpinan menjadi pemimpin. Untuk itu sangat penting mencari dan menemukan pemimpin yang transformasional; apa, mengapa, dan bagaimana Kepemimpinan Transformasinal menjadi pembahasan dalam tulisan ini, untuk menemukan kepemimpinan yang ideal, di tengah Krisis Kepemimpinan saat ini.

\section{Metode Penelitian}

Pada penelitian ini, penulis atau peneliti menggunakan pendekatan atau metode kualitatif untuk memperoleh data yang valid guna membangun sebuah teori yang berkaitan dengan tema atau pokok penelitian. Metode kualitatif yang dimaksud adalah mengkaji dan mengelaborasi setiap sumber, informasi dan data-data yang diperoleh dari pustaka.

\section{Hasil dan Pembahasan}

\section{Definisi Umum Transformasional}

Transformasional adalah bentuk yang berbeda namun mempunyai nilai-nilai yang sama, perubahan dari satu bentuk atau ungkapan menjadi suatu bentuk yang mempunyai arti atau ungkapan yang sama mulai dari struktur permukaan dan fungsi. ${ }^{2}$ Sedangkan dalam kamus Webster, transformasional diartikan sebagai perubahan menjadi sesuatu. Transformasi dapat dianggap sebagai sebuah proses pemulihan total dari suatu bentuk menjadi sebuah sosok baru; dapat diartikan sebagai tahap akhir dari sebuah proses perubahan yang dijalani secara bertahap, di mana faktor ruang dan waktu menjadi hal yang sangat mempengaruhi perubahan tersebut. ${ }^{3}$ Pendapat lain

\footnotetext{
${ }^{2}$ The New Grolier Webster International Dictionary of English Language, Encyclopedic Edition (Volumes 1 \& 2) (McGraw-Hill Children's Publishing, July 10, 1905).

${ }^{3}$ Webster's Dictionary. WordNet Lexical Database. Dictionary of Computing, Legal Dictionary, 1970.
} 
menyatakan bahwa, transformasi adalah perubahan fisik disebabkan oleh adanya kekuatan non fisik yaitu perubahan budaya, sosial, ekonomi, dan politik. ${ }^{4}$

\section{Transformasional menurut konsep Rasul Paulus}

Transformasi perilaku diawali oleh transformasi pikiran, yang Paulus sebut sebagai "pembaharuan budi". Yang dimaksud dengan perilaku (behavior) ialah karakter, sikap, perbuatan atau tindakan seseorang yang dapat dilihat (visible), diamati (observable), dan dapat diukur (measurable). Berbeda dengan transformasi posisi yang terjadi secara seketika, maka transformasi perilaku terjadi secara bertahap sebagai suatu proses. Alkitab menyebutnya dengan istilah "pengudusan" yang dinamis. Paulus mengatakan “...karena kamu telah menanggalkan manusia lama serta kelakuannya, dan telah mengenakan manusia baru yang terus-menerus diperbaharui untuk memperoleh pengetahuan yang benar menurut gambar Khaliknya" (Kol. 3:9-10). Ayat ini menjelaskan bahwa setelah lahir baru seseorang perlu terus-menerus mengalami proses pengudusan yang mencakup pengudusan pikiran, kehendak, emosi, dan hati nurani, pengudusan sifat-sifat maupun perilaku kita. ${ }^{5}$ Selanjutnya, Paulus menasehati: "berubahlah oleh pembaharuan budimu'. Kata Yunani "nous" yang digunakan disini berarti "akal budi atau pikiran". Pembaharuan nous (pikiran) adalah syarat untuk bisa mengenal dan melakukan kehendak Allah. Apa yang diyakini oleh pikiran (nous) akan mempengaruhi perilaku (behavior) seseorang (Rm. 14:1-8). Pembaharuan akal budi akan menghasilkan hidup kudus. Dengan demikian pengalaman transformasi perilaku atau tindakan adalah hasil dari pembaharuan akal budi. Dalam Efesus 4:17-32, Paulus berbicara tentang transformasi perilaku, setelah sebelumnya mengalami transformasi posisi. Di sini terlihat, terjadi perubahan dari yang tidak baik menjadi baik, dari perilaku negatif ke perilaku positif.

Dari pernyataan Rasul Paulus di atas, terdapat tiga tingkat transformasional dalam kehidupan orang Percaya, yaitu: 1) Transformasi Posisi (Position Transformation); 2) Transformasi Perilaku (Behavior Transformation); dan 3) Transformasi komunitas (Community Transformation). Dalam pemahaman penulis, pengertian transformasi (versi Paulus) bertitik tolak dari Roma 12:2. Sesungguhnya ayat ini merupakan kunci dari transformasi dan menunjuk 3 (tiga) tingkat transformasi yang perlu dialami umat Tuhan, yaitu position transformation, behavior transformation, dan community transformation. Pertama dan kedua bersifat internal yaitu berada dalam setiap percaya, sedang yang ketiga bersifat eksternal yaitu sebagai akibat dari transformasi internal.

\section{Tranformasional dalam Gereja Masa Kini}

Transformasi menjadi kata yang begitu populer di kalangan Gereja-gereja di Indonesia. Ada yang memandang positif gerakan ini, tetapi ada juga yang menanggapinya dengan pesimis, bahkan cenderung menolaknya. Inti dari transformasi adalah terjadinya perubahan ${ }^{6}$. Sejak tahun 2000, Jaringan Doa Nasional (JDN) menjadi fasilitator gerakan doa transformasi kota di Indonesia, telah menyelenggarakan

\footnotetext{
${ }^{4}$ http://www.ar.itb.ac.id/wdp/wpcontent/uploads/2009/09/definisi_transformasi.

${ }^{5}$ Tujuan akhir dari proses pengudusan yang dinamis ini yang melibatkan kuasa Roh Kudus dan firman Allah adalah agar diri manusia diubah menjadi serupa dengan gambar Kristus, Khalik atau Pencipta. Pada mulanya manusia diciptakan menurut gambar dan rupa Allah.

${ }^{6}$ Wasis Suseno, "Transformasi Realita atau Angan-angan". Majalah Integrity. Edisi 1, Vol. 1 (Jakarta: CWS, 2009), 46.
} 
beberapa acara berskala nasional, konferensi, seminar, pelatihan, dan Kebaktian Kebangunan Rohani, dengan mengundang pembicara-pembicara terkenal di dunia seperti: Rev. Rick Warren, Rev. Cindy Jacob, Jeff Hammon, Alice Smith, John Kingley Alley, dan lainnya. ${ }^{7}$

Bila menelusuri gerakan Transformation Movement, atau yang lebih dikenal dengan Gerakan Transformasi Bangsa, maka tidak bisa dipisahkan dari beberapa tokoh-tokoh yang menjadi fasilitator, antara lain Niko Njotorahardjo, Bambang Widjaja, Eddy Leo, Ery Prasadja, Iman Santoso, Jeff Hammond, Rachmat Manulang, Jonathan Pattiasina, dan Daniel Pandji. ${ }^{8}$ Hammond menjelaskan, bahwa pada masa pergolakan di Indonesia, sejak mei 1997, ada banyak nubuatan yang sangat signifikan tentang rencana Tuhan untuk membawa transformasi ke Indonesia. ${ }^{9}$ Hammond menyebut lima nubuatan: pertama, akan terjadi goncangan ekonomi di Indonesia; kedua, goncangan itu akan menyebabkan Presiden yang menjabat digulingkan; ketiga, setelah itu akan muncul seorang presiden di dalam masa transisional; keempat, akan ada presiden wanita; dan kelima, Indonesia akan mengalami masa tuaian besar. Satu per satu nubuatan-nubuatan itu sedang digenapi. ${ }^{10}$

Gerakan transformasi bangsa di Indonesia memandang tahun 2005 sebagai tahun penuaian dan tahun 2020 sebagai tahun penggenapan Amanat Agung di Indonesia. Maksudnya, pada tahun itu, Indonesia akan berangsur-angsur berubah dari impian menjadi kenyataan. Salah satu bentuk transformasi Indonesia adalah terjadinya pertobatan sejati yang akan membawa berjuta-juta orang untuk mengenal dan menerima Tuhan Yesus Kristus sebagai Juruselamat pribadi. Hammond akhirnya mendesak kaum Kristen (tokoh-tokoh) lain dalam Gerakan Transformasi seperti Rachmat Manulang, sebagai mantan Ketua Umum Jaringan Doa Nasional Periode 2001 2006, penggagas acara yang berskala nasional. Rachmat berpendapat, bahwa kaum Kristen untuk segera berbuat, karena kondisinya sudah sangat genting dan kesabaran Tuhan hampir habis. Bangsa Indonesia harus segera menyembah Tuhan, jika tidak bangsa ini akan mengalami kehancura. ${ }^{11}$

Ungkapan Manulang di atas menempatkan Indonesia sebagai daerah yang mendapatkan janji khusus, sesuai dengan gambaran Kitab Yesaya 60:7-9. Sebab, Indonesia adalah keturunan Kedar Nebayot. Indonesia adalah keturunan Ismael Rohani terbesar, lebih besar dibandingkan dengan seluruh penduduk Timur Tengah. Karena itu, "umat Tuhan harus setia memberikan yang terbaik, baik uang, pikiran, daya, atau apa pun dan menyerahkannya kepada Tuhan agar Ia menjamahnya sehingga terjadi multiplikasi sumber daya yang luar biasa." 12 Sejak para misionaris masuk ke Indonesia, sangat ditekankan peran gereja. Tugas gereja sebagai satu organisme yang telah ditebus oleh darah Kristus adalah meneruskan karya salib bagi banyak manusia yang dikasihiNya, yaitu mereka yang bukan saja belum menerima Kristus sebagai Juruselamat pribadi mereka, melainkan juga mereka yang tertindas dan diperlakukan tidak adil. Dalam hal ini, Gereja adalah alat yang dipilih Tuhan untuk menjadi agen transformasi.

\section{Konsep Terjadinya Transformasi Bangsa}

\footnotetext{
${ }^{7}$ Suseno, "Transformasi Realita atau Angan-angan", 47.

8 Transformasi Indonesia: Pemikiran dan Proses Perubahan yang Dikaitkan dengan Kesatuan Tubuh Kristus (Jakarta: Metanoia, 2003), 27.

${ }^{9}$ Jeff Hammond, Transformasi: Kairos bagi Indonesia (Jakarta: Metanoia, 2003), 24.

${ }^{10}$ Hammond, Transformasi, 27.

${ }^{11}$ Hammond, Transformasi, 27.

${ }^{12}$ Transformasi Indonesia, 27.
} 
Ada lima indikator transformasi (berdasarkan konsep Discipling A Whole Nation (DAWN) yang didasarka pada Yesaya 9:1-10.

Pertama, Sebagai Garam dan terang. Pengaruh kekristenan sebagai garam dan terang di tengah-tengah kehidupan masyarakat, adalah: 1) mewujudkan kehidupan masyarakat perkotaan yang damai sejahtera melalui kehidupan spiritulaitas yang saleh dan baik. 2) Berita baik dapat diterima dan disampaikan dengan penuh sukacita, sehingga terjadi kegerakan rohani di tengah-tengah masyarakat. 3) Peranan media elektronik sebagai sarana untuk mempengaruhi tingkah laku dan moral masyarakat, agar nilai-nilai kristiani dapat dipraktekan. 4) Gaya hidup umat Kristen seperti Kristus. 5) Falsafah dan ajaran Kristen yang mempengaruhi kebijakan public dapat dilegalisasikan dalam wujud undang-undang.

Kedua, Kecukupan Ekonomi (Economi Sufficieny): "mereka telah bersukacita di hadapan-Mu, seperti sukacita di waktu panen" (Yes. 9).

\section{IDEAL}

"Maka tidak akan ada orang miskin di antaramu" (Ul. 15:7)

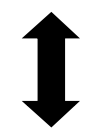

\section{REALITAS}

"Sebab orang-orang miskin tidak hentinya akan ada di dalam negeri itu" (Ul. 15:11)

Ketiga, Kedamaian Sosial (Social Peace): "dan namanya disebut orang: Raja Damai, sejahtera tidak akan berkesudahan" (Yes. 9:5-6). Kedamaian sosial, wujud kehidupan social peace di dalam masyarakat dengan terciptanya hubungan antar etnis yang rukun dan harmonis, terjadi rekonsiliasi antar umat beragama dan kelompok etnis, kebebasan beragama untuk semua agama secara konkret, terjadinya penurunan angka kriminalitas dan kenakalan remaja serta kekerasan, serta adanya penghargaan terhadap nilai-nilai kemanusiaan berdasarkan firman Tuhan.

Keempat, Keadilan Masyarakat (Publik Justice): "Karena Ia mendasarkan dan mengokohkannya dengan keadilan...” (Yes. 9:6). Aspek penegakan hukum yang benar dilaksanakan dengan menciptakan peradilan yang bersih, di mana hak maupun kewajiban dan undang-undang yang diterapkan didasarkan pada nilai-nilai kebenaran Kristen. Hal ini tidak memberi tempat pada praktek-praktek korupsi terjadi di ruang pengadilan, di mana hukum dapat dibeli, yang salah dibenarkan dan yang benar disalahkan, karena hakim dan jaksa dapat disuap. Hukum tidak boleh diperdagangkan oleh siapa pun di pengadilan.

Kelima, Kebenaran Bangsa: “dengan...kebenaran dari sekarang sampai selamalamanya" (Yes. 9:6; bdk. Ams. 14:34). Lembaga-lembaga gerejawi di Indonesia dapat dipersatukan (bdk. Yoh. 17), sehingga bekerja sama dan bersinergi, peduli terhadap keadaan di sekitarnya.

\section{Pengertian Gereja Masa Kini di Era Post Moderen}

Kitab Perjanjian Lama memakai dua istilah untuk menunjuk gereja, yaitu: qahal yang artinya memanggil dan edhah yang artinya memilih atau menunjuk atau bertemu bersama-sama disatu tempat yang telah ditunjuk. Sedangkan Perjanjian Baru memakai istilah ekklesia yang artinya memanggil keluar, dan ini sering digunakan untuk 


\section{Wasis Waseso}

berkumpul beribadah secara umum. Kata ekklesia juga ditafsirkan dari penggunaan kata "ek" berarti: keluar dari sekumpulan orang-orang."13 Jadi, gereja yang didasarkan kepada istilah ekklesia adalah pertemuan orang-orang yang dipanggil keluar dari sebuah kumpulan kepada kumpulan yang baru untuk mencapai tujuan bersama ditempat yang telah ditentukan.

Gereja yang juga sering disebut sebagai jemaat tidak mengandung arti bahwa perkumpulan yang dilakukan adalah atas dasar keinginan sendiri untuk berkumpul, tetapi Kristuslah yang dengan perantaraan firman dan Roh mengumpulkan bagi-Nya jemaat."14 Dengan demikian, gereja atau mengalami pengertian yang lebih spesifik yang mengarah kepada kumpulan yang khusus yang disebut Kristen, yaitu kumpulan orangorang yang dipanggil oleh Kristus keluar dari kegelapan karena dosa kepada terang Kristus yang ajaib melalui firman dengan pertolongan Roh Kudus. Jadi, gereja bukanlah menunjuk kepada gedung sebagaimana yang didefinisikan oleh Kamus Besar Bahasa Indonesia (Gereja adalah gedung atau rumah tempat berdoa dan melakukan upacara agama Kristen). ${ }^{15}$ Para ahli teologia mengatakan, Gereja adalah individu yang juga disebut "organisme yang hidup"16, yaitu setiap orang yang percaya kepada Injil yaitu Yesus, yang berhimpun bersama untuk bersekutu di suatu tempat yang telah ditentukan bersama dengan melakukan upacara keagamaan yaitu upacara persekutuan dengan Allah.

George W. Peter menyatakan, bahwa

Gereja adalah lembaga keempat yang dibentuk oleh Allah sendiri. Yang pertama adalah keluarga, kedua adalah pemerintahan, ketiga adalah penetapan bangsa Israel sebagai umat Allah, dan yang terakhir adalah gereja. Sementara gereja mempunyai berbagai kesamaan ciri dengan lembaga yang lain, ia adalah unik dalam hal kelahirannya, rencana, misi, dan tujuannya. ${ }^{17}$

Pendiri, inisiator, dan Kepala gereja adalah Tuhan Yesus, sebagaimana tercatat dalam Injil Matius 16:18, "Dan Akupun berkata kepadamu: Engkau adalah Petrus dan di atas batu karang ini Aku akan mendirikan jemaat-Ku dan alam maut tidak akan menguasainya." Kata ekklesia di sini menunjukkan bahwa gereja berdiri di atas pengakuan percaya bahwa Yesus adalah Anak Allah yang hidup. Gereja dibangun di atas dasar rasul-rasul dan nabi-nabi, dan Yesus Kristus sendiri menjadi batu penjuru utama.

Gereja adalah tubuh Kristus (1 Kor. 12:27). Kristus adalah Kepala Gereja, memilih anggota-anggota tubuh-Nya dan setiap bagian itu memiliki arti penting yang sama (1 Kor. 12:12-26). Sama seperti tubuh manusia, setiap bagian mempunyai fungsi yang berbeda (Ef. 4; Rm. 12; 1 Kor. 12-14). Dalam gereja mula-mula, setiap orang percaya bertugas sebagai tubuh Kristus dengan menggunakan karunia rohani mereka saat mereka berhubungan dengan yang lain. Allah menganugerahkan karunia-Nya sehingga anggota tubuh dapat memakainya bagi kesejahteraan dan kemajuan seluruh tubuh itu. ${ }^{18}$

Salah satu gambaran utama tentang gereja dalam PB adalah "Tubuh Kristus" (Rm. 12:4; Kol. 1:18). Tubuh Kristus menjelaskan tentang organisme, bukan benda mati

${ }^{13}$ Louis Berkhof, Teologi Sistematika: Doktrin Gereja (Jakarta: Lembaga Reformed Injili Indonesia, 1997), $5-7$.

${ }^{14}$ G. C. Van Niftrik dan B. J. Boland, Dogmatika Masa Kini (Jakarta: BPK Gunung Mulia, 2001), 359.

${ }^{15}$ Kamus Besar Bahasa Indonesia, 1994.

${ }^{16}$ Joel Comiskey, Menuai Tanpa Batas (Jakarta: Metanoia, 2003), 61.

${ }^{17}$ George W. Peters, Teologia Pertumbuhan Gereja (Malang: Gandum Mas, 2002), 54.

${ }^{18}$ Peters, Teologia Pertumbuhan Gereja, 24. 
(gedung gereja) atau kumpulan orang semata. Tubuh sebagai organisme perlu diperbaharui terus-menerus dan sel-sel tubuh harus bertumbuh, jika tidak ia akan sakit, menua, dan mati. Kata koinonia (persekutuan) tidak menyiratkan sebuah kondisi stagnasi (macet) atau pun mati. Persekutuan menjelaskan satu aliran komunikasi, saling membagi (sharring in common, 1 Kor. 10:16), saling memberi kontribusi (Rm. 15:26; 2 Kor. 8:4), ada gerak dan ada dinamika.

Berkouwer mengatakan bahwa, hubungan diri Kristus dan jati diri gereja, yaitu diri Kristus (atau tubuh-Nya) dapat lebih murni dipahami hanya dalam semua relasi dan aspek jati diri gereja. Berdasarkan keintiman hubungan diri Kristus dengan tubuh-Nya (gereja), maka terdapat tiga pemahaman utama yaitu, Kepala, Tubuh dan Anggota. ${ }^{19}$ Pertama, Kepala Gereja. Kristus adalah Kepala Gereja (Ef. 4:15). Kata kepala berarti sumber otoritas dan dasar kreativitas, terutama Raja, Pre-eksistensi dan Dasar. Dalam hal ini, pemahaman Kristus adalah Kepala Gereja berarti menekankan keutamaan Kristus, sumber otoritas, Raja, dasar dan kepemimpinan Kristus. Peranan Kepala Gereja sangat menentukan eksistensi gereja dan kehidupan seluruh komunitas anggota gereja. Ia adalah Kepala di mana melalui, oleh, dan kepada Dia mengalir kehidupan kepada tubuh-Nya. Dia menciptakan dan memelihara gereja-Nya. Gereja mendapat pengampunan dosa dan anugerah hanya di dalam Dia. Ia memanifestasikan bijaksana, kuasa dan otoritas, kasih dan keadilan, iman dan pengetahuan serta segala kekayaan dalam gereja. R. B. Kuiper mengatakan bahwa, Kristus memerintah gereja-Nya melalui Firman dan Roh-Nya ${ }^{20}$. Kristus menambahkan jumlah anggota gereja melalui anugerahNya yang tak bersyarat dari karya Roh Kudus, yakni melalui panggilan yang efektif dengan Firman-Nya yang berotoritas. Pertumbuhan gereja adalah pertumbuhan firman Tuhan. Gereja yang bertumbuh bukan hanya mengabarkan firman yang sejati, melainkan juga mengaktualisasikan atau menaati firman-Nya, baik dalam menjalankan konteks mandat budaya maupun mandat Injil.

Kedua, Tubuh Kristus. Tubuh Kristus adalah komunitas orang kudus. Dalam Kristus, komunitas ini telah dipisahkan dari kematian tubuh dalam dosa kepada tubuh yang hidup berdasarkan kuasa Roh Kudus (Rm. 7:24). Orang percaya telah mati bagi hukum Taurat melalui tubuh Kristus dan kematian-Nya, dan hidup dalam anugerah Tuhan. Kini komunitas ini telah hidup baru dalam kebangkitan-Nya, di mana mereka telah serupa dengan kematian-Nya melalui baptisan dalam kematian-Nya (Rom 6:3). Jadi, eksistensi tubuh Kristus tidak dapat dilepaskan dari pribadi dan karya Kristus di atas kayu salib dan kebangkitan-Nya dari antara orang mati. Partisipasi dalam tubuh Kristus berarti partisipasi baik dalam kematian-Nya maupun dalam kebangkitan-Nya. Melalui peristiwa penyelamatan ini, manusia memiliki jaminan berdasarkan karunia Roh Kudus dalam hatinya dan kuasa untuk hidup bagi Kristus.

Tubuh Kristus secara organik bertumbuh ke arah Kristus. Tubuh Kristus bertumbuh tatkala firman Tuhan dibiarkan berkuasa secara leluasa. Tubuh mengalami pertumbuhan tatkala gereja menaati firman Tuhan untuk hidup secara harmonis dengan anggota yang lain dalam kasih, sukacita, ucapan syukur dan nyanyian rohani (Kol. 3:1516). Hal ini berarti bahwa seluruh pelayanan, motif, dan usaha gereja harus diarahkan kepada sasaran dari Kepala. Kehidupan tubuh Kristus secara total bergantung pada Kepala tubuh. Relasi tubuh Kristus dan kepala tubuh telah membuat pertumbuhan

${ }^{19}$ Gerrit Berkouwerm, “Dinamika dalam Doktrin Pilihan”, dalam Jurnal Pelita Zaman, Vol. 8, Thn 1, 1993 (Malang), 14-15.

${ }^{20}$ R. B. Kuiper, The Glorious Body of Christ (Grand Rapids, Michigan: Eerdmans, 1965), 95. 


\section{Wasis Waseso}

gereja menjadi unik, rahasia dan dinamis. Dengan demikian, pergumulan utama dari eksistensi gereja adalah memahami apa yang dikehendaki oleh Kepala tubuh, bukan apa yang dikehendaki oleh anggota jemaat, meski pun menganalisa kebutuhan anggota tubuh merupakan hal penting, tetapi bukanlah suatu hal yang sangat mendasar bagi kehidupan gereja tersebut. ${ }^{21}$ Pengenalan tubuh Kristus terhadap Kepala tubuh bukan merupakan pengetahuan hasil studi terhadap suatu obyek, melainkan karunia dari atas ke bawah melalui alat anugerah, misalnya doa dan puasa, merenungkan firman Tuhan, dan refleksi cara kerja Allah dalam sejarah wahyu.

Ketiga, Anggota Tubuh. Anggota tubuh dan tubuh Kristus mempunyai relasi yang erat dengan Kepala karena tubuh-Nya dan darah-Nya merupakan sumber utama kesatuan gereja. Setiap anggota berbeda satu dengan lainnya, namun mereka berada dalam satu kesatuan tubuh. ${ }^{22}$ Setiap anggota memainkan peranan yang berbeda sesuai dengan karuni yang diberikan Roh padanya, namun segala karunia tersebut dipakai untuk melayani Kristus sebagai Kepala dan membangun tubuh Kristus. Anggota tubuh dalam kehidupan bersama mengenakan pola pikir yang baru. Pola pikir baru yang dimaksud adalah berorientasi pada mementingkan keutamaan Kepala dan tubuh Kristus sehingga memungkinkan terjadinya kehidupan harmonis dan bertumbuh secara maksimal dengan anggota yang lain. ${ }^{23}$ Anggota Gereja perlu saling bergantung satu dengan lainnya, saling membutuhkan, memperhatikan, menghormati dan berempati (1 Kor. 12:21-26) Berdasarkan konsep dinamis tentang Kepala, Anggota tubuh, dari Tubuh Kristus, maka dapat disimpulkan bahwa:

1) Gereja adalah komunitas orang kudus, yang secara total bergantung pada karya Kristus yang menyelamatkan, yakni melalui kematian dan kebangkitan-Nya. Ia adalah Kepala Gereja dan Sumber kehidupan tubuh Kristus, yang melalui-Nya segala kuasa, pengetahuan dan kasih mengalir ke dalam tubuh-Nya.

2) Gereja bersatu melalui saling mengasihi.

3) Ditinjau dari sudut pandang eskatologis, gereja secara progresif bertumbuh ke arah Kristus dalam kasih, iman dan pengetahuan dan hal tersebut akan digenapi dalam Kristus setelah akhir jaman.

\section{Prinsip-Prinsip Gereja}

Gereja dibangun atas dasar Kristus yang bangkit, yang hidup, yang adalah batu penjuru keberadaan gereja. Sebagaimana Tuhan itu hidup, demikian juga gereja-Nya, karena "alam maut tidak akan dapat menguasainya" (Mat.16:18). Hidup berkaitan erat dengan tumbuh. Salah satu gambaran utama tentang gereja dalam Perjanjian Baru adalah "Tubuh Kristus" (Roma 12:4; Kol. 1:18). Tubuh Kristus menjelaskan tentang "organisme" bukan benda mati (gedung gereja) atau kumpulan orang semata. Tubuh sebagai organisme perlu diperbaharui terus menerus dan sel-sel tubuh harus bertumbuh, jika tidak ia akan sakit, menua, dan mati. ${ }^{24}$ Kata koinonia (persekutuan) sendiri dalam definisi gereja sebagai "persekutuan orang percaya" tidak menyiratkan stagnasi (macet) ataupun mati. Persekutuan menjelaskan satu aliran komunikasi, saling membagi (Sharring in Common, 1 Kor. 10:16), saling memberi kontribusi (Roma 15:26; 2 Kor. 8:4), ada gerak dan ada dinamika.

\footnotetext{
${ }^{21}$ Kuiper, The Glorious Body of Christ, 91.

${ }^{22}$ William Barclay, Karunia-Karunia (Jakarta: BPK Gunung Mulia, 1995), 27.

${ }^{23}$ Barclay, Karunia-Karunia, 30.

${ }^{24}$ Barclay, Karunia-Karunia, 30
} 
Beberapa prinsip-prinsip penting tentang Gereja, diambil dari beberapa sumber menyebutkan bahwa: Pertama, Berpusat pada Allah. John Stott menekankan bahwa gereja bukan sebuah kecelakaan sejarah melainkan merupakan pusat dari rencana Allah. Rencana Allah dalam gereja bukanlah rencana sementara melainkan menuju kepada kekekalan, yakni rencana yang akan membawa umat-Nya dalam keselamatan yang kekal. Setiap orang yang sudah diselamatkan mempunyai tanggung jawab untuk memberitakan Injil bagi mereka yang belum percaya, hal ini terus disampaikan secara berulang-ulang diperintahkan kepada murid-murid-Nya. Kedua, Yesus Kristus adalah Tuhan (Flp. 2:11). Ketiga, Kemuliaan Allah menjadi tujuan utama. Allah telah memanggil umat-Nya untuk menjadi umat yang kudus, menjadi saksi kemuliaan Allah. Keempat, Kepemimpinan adalah salah satu Jawatan Gereja. Dalam Efesus 4:11 dinyatakan bahwa Allah memberikan 5 jawatan Gereja untuk perngembangan sesuai dengan kepenuhan Kristus.

Prinsip-prinsip Gereja tentu masih dipertahankan, walaupun ada berbagai tantangan yang harus dihadapi. Tak dapat dipungkiri bahwa era postmodernisme bisa menjadi tantangan atau bahkan hambatan tersendiri bagi para pemimpin Gereja. Imbasnya, Gereja bisa menjadi terancam ketika para pemimpinnya tidak memahami bagaimana menghadapi era postmodernisme.

\section{Apakah Era Postmoderenisme itu?}

Hali Daniel Lie dalam artikelnya yang berjudul "Abad Pertengahan, Modernisme dan Posmodernisme" menjelaskan bahwa, "dalam sejarah kehidupan manusia dikenal tiga era atau zaman yang memiliki ciri khasnya masing-masing, yaitu: pramodern, modern dan postmodern."25 Junior Natan Silalahi menjelaskan pula, bahwa

pemikiran masa pramodern selalu menempatkan Allah sebagai pusat dari segala pemikiran, kebudayaan dan masyarakat. Pusat dari seluruh kehidupan manusia adalah persoalan dengan Allah. Pada masa pramodern, teologi dijadikan sebagai 'ratu ilmu pengetahuan'. Segala sesuatu diukur dan harus diuji berdasarkan Alkitab. Sedangkan zaman modern ditandai dengan afirmasi diri manusia sebagai subjek. Melalui pernyataan tersebut, manusia dibimbing oleh rasionya sebagai subjek yang berorientasi pada dirinya sendiri sehingga rasio atau akal budi manusia menjadi pengendali manusia terutama tingkah lakunya. Kemampuan rasio menjadi kunci kebenaran pengetahuan dan kebudayaan modern. Konstruksi kebudayaan modern kemudian tegak berdiri dengan prinsip-prinsip rasio. ${ }^{26}$

Silalahi menambahkan,

Pada abad 19 dan 20 Era modern memang banyak menghasilkan kemajuan di berbagai bidang kehidupan manusia, akan tetapi hal itu juga membawa dampak negatif dengan terjadinya berbagai peristiwa buruk, misalnya Perang Dunia I (19141918), kemudian disusul dengan Perang Dunia II. Selain itu, terjadinya polusi yang hebat, pencemaran lingkungan besar-besaran, eksploitasi tenaga kerja, perbudakan,

${ }^{25}$ Hali Daniel Lie, Abad Pertengahan, Modernisme dan Posmodernisme (Jurnal Teologi Stulos 5, 2009), 19, dikutip oleh Junior Natan Silalahi, "Pengaruh Postmodernisme pada Teolog di Indonesia". http://sekolahtinggiteologicovenan.blogspot.com/2015/08/normal-0-false-false-false-in-x-none-x.html?m=1.

${ }^{26}$ Silalahi, "Pengaruh Postmodernisme pada Teolog di Indonesia". 


\section{Wasis Waseso}

penjajahan (imperialisme), pembersihan etnis (tribalisme) di beberapa tempat (misalnya: Bosnia, Somalia, Rwanda), kualitas kejahatan yang meningkat, perpecahan suku bangsa, dan perang yang tak kunjung padam di beberapa negara di dunia. Dari pengalaman buruk di atas, maka lahirlah apa yang disebut sebagai postmodern. ${ }^{27}$

Guru besar bidang sejarah gereja di Sekolah Tinggi Teologi (STT) Jakarta, Jan S. Aritonang, menyatakan bahwa masyarakat Gereja harus menyamakan pemahaman terlebih dahulu apa yang dimaksud dengan postmodern. Lebih lanjut, Aritonang menjelaskan, Postmodernisme yang awalnya merupakan reaksi di kalangan filsuf Barat terhadap modernisme ditandai oleh pengagungan terhadap rasio. ${ }^{28}$ Menurut Aritonang, postmodernisme membawa kritik yang tajam terhadap filsafat, bahkan pada era postmodern filsafat sudah mati. Pada era pencerahan atau modern, para peneliti mengajukan kritik terhadap isi Alkitab. Alkitab dibeda dengan berbagai metode, seperti kritik redaksi dan bahasa, serta kritik historis sehingga muncul pendapat bahwa Alkitab bukanlah kitab yang utuh ataupun lengkap. Kebenaran tersebut tidak dapat dibuktikan atau diterima secara ilmiah karena perlu rekonstruksi, demitologisasi, dan penafsiran secara baru, selain dilengkapi dan dibandingkan dengan beberapa tulisan lain. Pemahaman kalangan Postmodernis tentang agama merupakan reaksi terhadap fundamentalisme. Fundamentalisme di kalangan Kristen muncul terutama di Amerika Serikat pada 1920.29

Menurut H. W. B. Sumakul, awalan "post" dalam kata postmodernitas mempunyai dua arti: pertama, "putus hubungan dari" modernitas, dan kedua, "sesudah" atau "kelanjutan dari" modernitas. Arti pertama adalah suatu diskontinuitas dari yang modern, sedangkan arti kedua adalah kontinuitas dari yang modern. ${ }^{30}$ Apabila postmodernitas adalah diskontinuitas dari yang modern, ini berarti antara era modern dan era postmodern putus hubungan sama sekali. Era postmodern memisahkan diri dari era modern secara mutlak dan radikal. Dan arti yang kedua, apabila postmodernitas merupakan kontinuitas era modern maka era postmodernitas tidak bisa dipisahkan dari era tersebut. ${ }^{31}$ Menurut Silalahi, apabila disebut postmodernitas sebagai 'putus hubungan' dengan era modern maka hal ini tidaklah mungkin. Postmodernitas lebih dekat kepada definisi bahwa era ini merupakan kelanjutan dari era sebelumnya, yaitu era modern. Postmodernitas tidak bermaksud menolak dan menyangkali akan hasilhasil dari modernitas, melainkan lebih kepada sikap mengkritik pemahaman yang ada dibalik modernitas itu sendiri. Jadi Postmodernisme adalah paham yang tidak mengakui adanya kebenaran mutlak (absolute), melainkan menerima relativitas kebenaran dan keberbagaian kebenaran. ${ }^{32}$

Jadi, dapat disimpulkan bahwa postmodern menolak segala kebenaran objektif dan mutlak. Satu-satunya kebenaran yang layak dipercaya adalah "kebenaran bersifat relatif." Kepercayaan terhadap akal budi digantikan dengan kepercayaan terhadap pengalaman atau perasaan tiap-tiap individu berdasarkan pengalaman.

27 Stanley J. Grenz, A Primer on Postmodernism. (Yogyakarta: Andi, 2001), 13. Dikutip Silalahi, "Pengaruh Postmodernisme pada Teolog di Indonesia".

28 Jan S. Aritonang, "Kuliah Umum” dalam Rangka Dies Natalis ke-80 Sekolah Tinggi Teologi (STT) Jakarta, 25 September 2016.

${ }^{29}$ Aritonang, "Kuliah Umum".

30 H.W.B. Sumakul, Posmodernitas (Jakarta: BPK Gunung Mulia, 2012), 7 dikutip Silalahi, "Pengaruh Postmodernisme pada Teolog di Indonesia".

${ }^{31}$ Silalahi, "Pengaruh Postmodernisme pada Teolog di Indonesia".

${ }^{32}$ Silalahi, "Pengaruh Postmodernisme pada Teolog di Indonesia". 
Yongky Karman secara meyakinkan mengatakan, bahwa

Postmodernisme menyerang status khusus kebenaran yang satu, universal, total, dan absolut sebagaimana dipahami dalam modernisme. Kebenaran tunggal dan universal tidak diakui. Yang ada hanya kebenaran-kebenaran yang benar untuk setiap masyarakat atau komunitas. Maka kebenaran dipahami sebagai terpecah-pecah ke dalam kebenaran-kebenaran yang sederajat tanpa acuan normatif tunggal di luarnya. Tidak ada tradisi atau ideologi yang berdiri di atas tradisi yang lain atau ideologi yang lain. Yang diyakini seseorang sebagai benar bukan lagi kebenaran tunggal melainkan bagian dari pluralisme kebenaran. ${ }^{33}$

Sedangkan menurut Stanley J. Grenz, filsafat postmodern menerapkan teori dekonstruksi kepada realitas. Sebagaimana setiap teks dibaca secara berbeda, demikian juga realitas akan dibaca berbeda oleh setiap orang yang menghadapi realitas tersebut. Ini berarti tidak ada makna tunggal dalam dunia, tidak ada titik pusat sebuah realita. ${ }^{34}$ ini berarti postmodern tidak mengizinkan adanya klaim kebenaran yang absolut dan pembuktian kebenaran yang mutlak atau kebenaran tertinggi di atas kebenaran lain. Setiap orang bebas menafsirkan setiap realitas tanpa suatu standar apapun dan semuanya harus diakui dan dihargai sebagai kebenaran. Kebenaran bersifat relatif, kebenaran bergantung pada setiap subjek. Namun demikian sebenarnya kebenaran bagi postmodern bukan sepenuhnya subjektif individualis. Subjektivitas postmodern adalah subjektivitas komunal, sebab kebenaran merupakan kesepakatan komunal. Grenz mengatakan: cara pandang postmodern menjadikan komunitas sebagai dasar pemahaman kebenaran..$^{35}$ Oleh karena penentu kebenaran adalah komunitas, maka tidak ada kebenaran yang mutlak dan kekal. Semua kebenaran bersifat relatif dan fluktuatif. Mereka menegaskan bahwa kebenaran hanyalah aturan-aturan dasar demi kesejahteraan komunitas tempat kita berada. ${ }^{36}$ Dengan demikian keputusankeputusan pribadi tidak dianggap penting, karena setiap pribadi hendaknya menyesuaikan diri dengan komunitas. Orang-orang individulis dan tidak dapat menyesuaikan diri dengan komunitas akan tersingkir.

Meskipun dalam banyak hal para ahli sendiri belum memiliki kata sepakat namun pada intinya bahwa postmodern menolak metanarasi, kebenaran mutlak, objektif dan universal. Sebagai gantinya menawarkan formula relatif, subjektif, dan komunal. Sedangkan dalam tataran aplikatif postmodern meninggalkan individualisme, religiositas, rasionalitas dengan memberikan alternatif komunalisme (kebersamaan dalam komunitas), spiritualitas (spiritualitasdi terangkan sebagai hal yang berbeda dengan religiositas, karena spiritualitas diartikan sebagai kondisi bathin yang merdeka bebas dari doktrin-doktrin agama), dan eksperimentalitas.

\footnotetext{
${ }^{33}$ Yongky Karman, Pengaruh Postmodernisme dalam Pendidikan. Makalah yang retreat Guru Kristen di Shekinah Village Depok, 23-25 Sept, 2006.

${ }^{34}$ Stanley J. Grenz, A Primer On Postmodrenism (Yogyakarta: Andi Offset, 2001), 14.

${ }^{35}$ Grenz, A Primer On Postmodrenism, 14.

${ }^{36}$ Grenz, A Primer On Postmodrenism, 18.
} 
Wasis Waseso

Penerapan untuk Meningkatan Peran Pemimpinan Gereja di Era Post Moderenisme

Ada 3 Peran yang ingin ditingkatkan dalam Kepemimpinan Gereja, yaitu:

Pertama, kecakapan dalam kehidupan rohani (spiritual formation). Salah satu pengaruh postmodernisme pada Kepemimpinan Gereja di Indonesia sesungguhnya sangat kuat. Menurut Silalahi,

Ciri khas era postmo adalah "Pudarnya Kebenaran". Kebenaran absolute akan ditentang keras dan bila mungkin disingkirkan, demi relativitas. Relativisme akan segala sesuatu akan menguasai era postmo, di segala bidang termasuk bahkan akan meresapi dunia agama. Tak heran, akibat dari kencangnya arus relativisme akan memunculkan Antrophosentrisme (berpusat pada manusia). Manusia sebagai tolak ukur akan segala sesuatu. Segala sesuatu yang bertentangan dengan kemanusiaan akan "ditiadakan".37

Menurut Davin Ray Griffin dalam bukunya Tuhan dan Agama dalam Dunia Postmodern, hal tersebut menawarkan apa itu yang disebut dengan Teolo gi Postmodern. Ada beberapa ciri khas teologi postmodern. Pertama; Tuhan dalam postmodern tidak dimengerti sebagai sesuatu yang mengarah pada satu pribadi di luar dunia yang memberi pengaruh pada dunia. Kedua: secara epistemologis teologi postmodern berdasarkan pada pengakuan akan adanya persepsi non indarawi. Ketiga: dalam memandang alam, postmodern berdasar pada alternatif lain yaitu pandangan yang menyatakan bahwa perasaan dan nilai intrinsik merupakan ciri khas yang ada pada semua individu yang membentuk alam ${ }^{38}$ Untuk itu sangat penting, Para Pemimpin Gereja di era Post modernisme, memiliki kehidupan yang Theosentris, yang berpusat pada Tuhan, dengan membangun dan meningkatkan kecakapan dalam kehidupan rohani atau spiritual formation, yaitu di dalam kehidupan doa, iman, hubungan intim dengan Tuhan, kedewasaan karakter dan integritas. Mengapa hal ini penting karena di era Post modernisme, Tuhan hanya dianggap sebagai sesuatu yang ada yang tidak memberi pengaruh apa-apa.

Kedua, kecakapan dalam penguasaan ilmu teologi atau (theological proficiency). Joas Adiprasetya dengan mengutip David Tracy, menyimpulkan teologi postmodern demikian, "Wajah sesungguhnya dari postmodernitas, sebagaimana dilihat oleh Emmanuel Levinas dengan kejernihan yang sedemikian rupa, adalah wajah dari yang lain, wajah yang berseru, "Jangan membunuhku," wajah yang memaksa, melampaui Levinas, jangan menjerumuskan aku atau siapapun juga ke dalam kisah Agungmu. ${ }^{39}$

Betapa bahaya, bila pemimpin gereja tidak meyakini Alkitab sebagai sumber Pengajaran yang absolut, untuk meyakini isi Alkitab wahyu Allah dalam berteologia, untuk itu kecakapan dalam bidang ilmu teologi. Hal ini berkaitan dengan penguasaan, Biblical Theology, Systematic Theology, dan Historical Theology, siatu keharusan dan mutlak supaya secara Theologis kuat dan tidak abu-abu, sebagaimana yang dipaparkan Stevri Indra Lumintang, alam bukunya Theologi Abu-abu Pluralisme Agama.

\footnotetext{
${ }^{37}$ Silalahi, "Pengaruh Postmodernisme pada Teolog di Indonesia".

38 Davin Ray Griffin, Tuhan dan Agama dalam Dunia Postmodern (Yogyakarta: Kanisius), 35 dikutip Silalahi, "Pengaruh Postmodernisme pada Teolog di Indonesia".

${ }^{39}$ Davin Ray Griffin, Tuhan dan Agama dalam Dunia Postmodern (Yogyakarta: Kanisius), hlm 28, dikutip Joas Adiprasetya, Mencari Dasar Bersama (Jakarta: BPK Gunung Mulia, 2009), 27, dikutip oleh Silalahi, "Pengaruh Postmodernisme pada Teolog di Indonesia".
} 
Ketiga, kecakapan praktis dalam keterampilan misi, pelayanan Practical \& Ministry Proficieny. Dampak dari Peningkatan kecakapan kehidupan rohani yang sehat atau Spiritual Formation, dengan kecapakan dalam bidang ilmu Theologia atau Theological Proficiency, adalah kerinduan untuk melayani atau yang disebut dengan Practical \& Ministry Profiency.

\section{Kesimpulan}

Bila kita dapat gambarkan, kepemimpinan transformasi di era post moderen, harus memiliki tiga peran yang nyata dalam kepemimpinannya, seperti yang dapat dilihat dalam gambar di bawah ini:

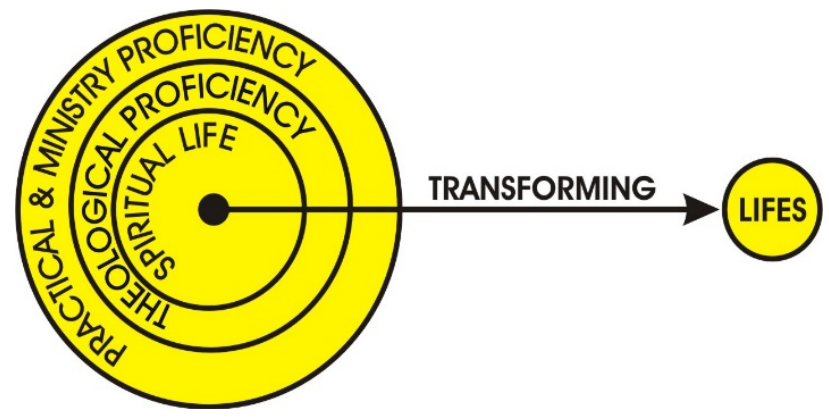

Kecakapan Practical \& Ministry Proficiency adalah kecakapan praktis dalam keterampilan misi, pelayanan dan juga kecakapan dalam keahlian teknis seperti kepemimpinan, manajemen, teknologi, dan administrasi gereja, yang sangat dibutuhkan diperlukan dalam kepemimpinan di Gereja Era Post moderinisme.

\section{Referensi}

Eka Dharma Putra, "Kepemimpinan dalam Pendidikan Agama Kristen", dalam kumpulan tulisan Bergumul Dalam Pengharapan (Jakarta: BPK Gunung Mulia, 2004).

The New Grolier Webster International Dictionary of English Language, Encyclopedic Edition (Volumes 1 \& 2) (McGraw-Hill Children's Publishing, July 10, 1905).

Webster's Dictionary. WordNet Lexical Database. Dictionary of Computing, Legal Dictionary, 1970.

http://www.ar.itb.ac.id/wdp/wpcontent/uploads/2009/09/definisi_transformasi.

Wasis Suseno, "Transformasi Realita atau Angan-angan". Majalah Integrity. Edisi 1, Vol. 1 (Jakarta: CWS, 2009).

Transformasi Indonesia: Pemikiran dan Proses Perubahan yang Dikaitkan dengan Kesatuan Tubuh Kristus (Jakarta: Metanoia, 2003).

Jeff Hammond, Transformasi: Kairos bagi Indonesia (Jakarta: Metanoia, 2003), 24.

Louis Berkhof, Teologi Sistematika: Doktrin Gereja (Jakarta: Lembaga Reformed Injili Indonesia, 1997).

G. C. Van Niftrik dan B. J. Boland, Dogmatika Masa Kini (Jakarta: BPK Gunung Mulia, 2001).

Joel Comiskey, Menuai Tanpa Batas (Jakarta: Metanoia, 2003).

George W. Peters, Teologia Pertumbuhan Gereja (Malang: Gandum Mas, 2002).

Gerrit Berkouwerm, "Dinamika dalam Doktrin Pilihan", dalam Jurnal Pelita Zaman, Vol. 8, Thn 1, 1993 (Malang). 
Wasis Waseso

R. B. Kuiper, The Glorious Body of Christ (Grand Rapids, Michigan: Eerdmans, 1965). William Barclay, Karunia-Karunia (Jakarta: BPK Gunung Mulia, 1995), 27.

Junior Natan Silalahi, "Pengaruh Po stmodernisme pada Teolog di Indonesia". http://sekolahtinggiteologicovenan.blogspot.com/2015/08/normal-0-false-falsefalse-in-x-none-x.html?m=1.

Jan S. Aritonang, "Kuliah Umum” dalam Rangka Dies Natalis ke-80 Sekolah Tinggi Teologi (STT) Jakarta, 25 September 2016.

Yongky Karman, Pengaruh Postmodernisme dalam Pendidikan, makalah yang retreat guru Kristen di Shekinah Village Depok, 23-25 Sept, 2006.

Stanley J. Grenz, A Primer On Postmodrenism (Yogyakarta: Andi Offset, 2001), 14. 